Chernobyl accident

\section{Reactor design not perfect}

Academician Vitalii Legasov, a deputy director of the Kurchatov Nuclear Energy Institute, last week said that the design of the RBMK reactor was partially to blame for the Chernobyl disaster. The official Soviet viewpoint, embodied in a Politburo statement last month, was that human "irresponsibility" and "lack of labour discipline" was the cause. Workers at the power station, the Politburo said, had carried out unauthorized experiments on the Number 4 reactor, when it was undergoing a routine shutdown.

Although he did not disagree with the accident scenario, Legasov added some important details. In an interview for Japanese television, he said that the workers had not only carried out the "experiment" without the appropriate experts being present, they had also committed the "unbelievable" error of "keeping the emergency cooling system out of operation".

The experiment, he said, was intended to ascertain how long a power supply (for operating the reactor's own housekeeping functions) could be maintained after switching to the standby diesel generators. Such an experiment, he maintained, should have been carried out only with the reactor completely shut down and steam generation stopped. This account is compatible with the speculations of Western experts (see Nature 322, 399; 1986), that attempts to draw energy from the reactor in these conditions, well below the designed power range for the RBMK, produced steam voids within the cooling system, which caused power surges that

\title{
Guatemala accused of political killings
}

Washington

The American Association for the Advancement of Science (AAAS) has submitted to President Vinicio Cerezo of Guatemala a grim catalogue of more than 200 political killings, "disappearances" and arbitrary detentions of Guatemalan academics and students between 1980 and 1985. Most are believed to have been killed with the approval or the tolerance of the military governments that ruled Guatemala between 1978 and last January.

The reports prepared by AAAS's commission scientific freedom and responsibility, urges President Cerezo, a civilian, to investigate the cases and to allow families to seek judicial redress. Most of the cases describe scientific and medical professionals who were shot or abducted by unidentified men. Estimates of the total number of political killings in Guatemala over the past 15 years range up to 100,000 .

After AAAS presented a similar report to the new civilian government of Argen-

could not be controlled by the slow-moving control rods of this type of reactor.

Where Legasov differs from the official Soviet viewpoint is in maintaining that not only were the "experimenting" workers at fault, but also the design team, who should have foreseen these events.

For some time, Legasov has been suggesting that the explanation of the Chernobyl disaster would be a complex one. Interviewed last month for the Soviet journal New Times, he described it as a "scarcely probable thing . . . a combination of several events, each of them scarcely probable either". The idea that the designers should be able to predict accidents is not entirely new to the Chernobyl coverage; interviewed by the Mos-

\section{Japan's sunset export industry}

\section{Tokyo}

THERE is nothing like an old solution for a new problem. For years, Japan's Ministry of International Trade and Industry (MITI) has been exhorting industry to export, export and export some more. Now the nation has a new problem: with the Japanese the longest-lived people in the world, there are soon going to be far too many old people. The MITI solution export them?

Under the "Silver Columbia '92" plan, Japan's old-age pensioners will be able to set off to foreign lands where they can live in peace and comfort supported by an everrising yen. Life back home would be much harder, given the poor provision for pensions and the unwillingness of the government to take on any new financial commitments.

MITI foresees the establishment of
Japanese villages of around 1,000 people each, with construction beginning in 1990. Of course, a few problems remain. Next year, MITI and the Japan External Trade Organization will work out where the villages should be and ways of tackling language barriers and supplying Japanese food. Countries will be selected in the light of climate, law and order, medical services, housing and popular sentiment towards Japan.

Although the Japanese government would negotiate with the prospective host country, MITI wants the private sector to run the scheme. It is not yet clear how foreign governments will react. Will they see it as a welcome transfer of "intellectual property" or just another case of "dumping"? Could a trade develop? And would Japan be happy to import a few pensioners from elsewhere? tina in 1984 detailing disappearances of $\mathbf{5 5}$ Argentinian scientists, the Argentine government requested forensic science assistance from AAAS to investigate the cases. Cerezo has pledged to foster greater respect for human rights and to reform the national police and security forces, but those in the military responsible for unlawful killings cannot be brought to justice until an amnesty declared by the outgoing military government is repealed. It is not clear whether Cerezo will be able or willing to repeal the amnesty.

Plans for an independent human rights commission on Guatemala with international representation have so far come to nothing, but the government has indicated that it may be willing to appoint a special ombudsman to investigate allegations of human rights abuses. In the meantime, one judge has been appointed to hear 1,400 writs of habeas corpus submitted by Grupo de Apoya Mutuo, a local human rights group.

Tim Beardsley

cow weekly Literaturnaya Gazeta in June, Academician Boris Semenov, deputy chairman of the State Committee for the Use of Atomic Energy, said that the safety systems at Chernobyl were sufficient to prevent any escape of radioactive material in even the worst scenario foreseen by the designers - clearly implying that some possibilities had been overlooked.

By placing the responsibility on the Chernobyl workers, the Politburo statement implicitly exonerated the RBMK design, which is one of the two basic types used in the current Soviet nuclear power programme. During the past few weeks, official statements have made it clear that there are no plans to phase out or close down RBMK-powered stations in the immediate future, although there have been some exhortations to the scientists to produce a "new, safer" generation of nuclear reactors as soon as possible. A need to express government confidence in the RBMK may well lie behind the appointment to the new post of All-Union Minister of Nuclear Energy of Nikolai Lukonin, formerly director of the RBMKpower stations at Leningrad (1976-83) and Ignalina, near Vilnius (1983-86). Behind the scenes, however, the government and party leadership may be less happy with the design. One of the four top officials dismissed in July as a result of the official inquiry into the accident was Ivan Emelyanov, who some 20 years ago was head of the design team that produced the RBMK. Retraining programmes for the staff of nuclear power stations, including computer simulation of accidents and emergencies, are being introduced, and the siting of some projected power-station is now said to be under review. 